\title{
Nutritional evaluation of millet at different seeding rates and cutting heights
}

\section{Avaliação nutricional do milheto submetido a diferentes taxas de semeadura e alturas de corte}

\author{
Lilian Monise MILKE'; Mariana CAMPANAㄹ; Giovani ANTÔNIO'; Jozivaldo Prudencio Gomes de MORAIS'; \\ Elissandra Maiara de Castro ZILIO²; Juliana Aparecida Alves dos SANTOS²; Tiago Antônio DEL VALLE,2 Araras - SP, Brazil
${ }^{2}$ Universidade de São Paulo, Faculdade de Medicina Veterinária e Zootecnia, Departamento de Nutrição e Produção Animal, Pirassununga - SP, Brazil \\ ${ }^{1}$ Universidade Federal de São Carlos, Centro de Ciências Agrárias, Departamento de Biotecnologia e Produção Vegetal e Animal,
}

\begin{abstract}
This study evaluated the effect of different seeding rates and cutting heights on production and composition of millet. Two randomized block design experiments were performed. In the first trial, 32 parcels $(1.2 \times 1.2 \mathrm{~m})$ were used for evaluation of seeding rate of 24,35, 50 and $60 \mathrm{~kg} / \mathrm{ha}$. Three cuts were carried out to evaluate plant height, fresh and dry mass yield, dry matter (DM), neutral detergent fiber (NDF), crude protein (CP) and acid detergent lignin (ADL) concentration and in situ DM and NDF digestibility. In the second trial, 20 parcels $(1.2 \times 3.0 \mathrm{~m})$ were used to evaluate 20, 30, 40 and $50 \mathrm{~cm}$ of cutting heights for two growing cycles, performing the evaluations previously listed. Seeding rate linearly increased plant height, fresh and dry mass production, and tended to linearly decrease dry matter in situ digestibility, without effects on forage composition. Cutting height had no effect on crude protein $(\mathrm{CP})$ concentration, but linearly increased plant height, dry mass production, DM content and tended to decrease NDF in situ digestibility and ADL content. Thus, the use of the highest evaluated seeding rates $(60 \mathrm{~kg} / \mathrm{ha})$ and cutting height $(50 \mathrm{~cm})$ increased forage production; however, the use of the lowest residual height increased forage quality.
\end{abstract}

Keywords: Digestibility. Forage production. Grazing management. Lignin. NDF.

\section{Resumo}

Os efeitos de diferentes taxas de semeadura e altura de corte na produção e composição bromatológica do milheto foram avaliados em dois experimentos executados em delineamento em blocos casualizados. No primeiro experimento, foram utilizadas 32 parcelas $(1,2 \times 1,2 \mathrm{~m})$ e avaliadas as taxas de semeadura de 24, 35, 50 e $60 \mathrm{~kg} / \mathrm{ha}$. Três cortes foram realizados para avaliar a altura das plantas, a produção de massa fresca e seca, os teores de matéria seca (MS), fibra em detergente neutro (FDN), proteína bruta (PB) e lignina, assim como a digestibilidade in situ da MS e da FDN. No segundo experimento, 20 parcelas $(1,2 \times 3,0 \mathrm{~m})$ foram usadas para avaliar o efeito das alturas de corte de $20,30,40 \mathrm{e}$ $50 \mathrm{~cm}$, sobre as variáveis previamente citadas. De acordo com o aumento da taxa de semeadura, houve aumento linear da altura das plantas e da produção de massa seca e fresca, além de uma tendência de redução linear da digestibilidade in situ da matéria seca, sem afetar a composição da forragem. A altura de corte não afetou a concentração de proteína bruta, mas aumentou linearmente a altura das plantas, a produção de massa seca e o teor de matéria seca e tendeu a reduzir a digestibilidade in situ da FDN e a concentração de lignina. Assim, o emprego de maiores taxas de semeadura $(60 \mathrm{~kg} / \mathrm{ha})$ e de altura de corte $(50 \mathrm{~cm})$ aumentam a produção de forragem, ao passo que menores alturas de corte aumentam a qualidade da forragem.

Palavras-chave: Digestibilidade. Produção de forragem. Manejo do pasto. Lignina. FDN. 
Correspondence to:

Tiago Antônio Del Valle

Universidade Federal de São Carlos, Centro de Ciências

Agrárias, Departamento de Biotecnologia e Produção Vegetal

e Animal

Rodovia Anhanguera, km 174

CEP 13600-970, Araras, SP, Brazil

e-mail: tiagodelvalle@cca.ufscar.br

Received: 04/03/2017

Approved: 01/12/2017

\section{Introduction}

Human population growth and development have increased demand for animal protein sources. Ruminants are useful in converting vast renewable resources from rangeland, pasture, and crop residues or other by-products into edible food for humans (GERBER et al., 2015). Grazing production systems are common in Brazil and animal production improvement seems essential for economic and environmental sustainability. In addition, knowledge about animal and plant relationships are important for grazing system optimization. Nutritional forage value manipulation associated with mass availability are the main factors that determine animal performance (NELSON, 2011).

Tropical grasses are usually used for ruminant feeding on Brazilian farms. Millet (Pennisetum glaucum (L.) is an annual tropical grass that has high environmental adaptation, great production and nutritional quality (JORNADA et al., 2008). Millet has been used in farms as soil cover, due to its high growth rate (SOUZA NETO et al., 2008; HIRATA et al., 2015). However, it could be also used for hay production (ANJUM; CHEEMA, 2016), grain yield (ALENCAR et al., 2015) and grazing (SCHWARTZ et al., 2003; BRUM et al., 2008; MONTAGNER et al., 2008; SCARAVELLI ET AL., 2008; CAMARGO et al., 2009; DA SILVA et al., 2014). In the South of Brazil, millet has been used for grazing during summer (SCHWARTZ et al., 2003) because of increased dry matter availability (RIZO et al., 2004). Castro (2002) described that since 1970-decade millet has been used in continuous grazing systems; however, studies focused on grazing management are scarce (CASTRO, 2002; HERINGER; MOOJEN, 2002; PEDROSO et al., 2009; LEÃO et al., 2012).

Pedroso et al. (2009) studied structural characteristics of pearl millet under rotational grazing and recommended lower resting periods to provide 1.5 to 2.0 new leaves, which improves green blade proportion. Castro (2002) evaluated different cutting height $(10,20,30$ and $40 \mathrm{~cm})$ and showed

that it affected pasture productivity and morphological structure. Response models indicated $29.2 \mathrm{~cm}$ as the best cutting height for maximum lamb daily gain. Heringer and Moojen (2002) studied nitrogen fertilization levels and found highest production at $464 \mathrm{~kg} / \mathrm{ha}$. Leão et al. (2012) observed no effect of millet cultivar on in vitro digestibility, although plants higher than $100 \mathrm{~cm}$ had lower digestibility.

Pasture establishment procedure and grazing management can affect plant structure and production. Forage availability and dry matter yield are associated with mass and density of tiller. In addition, cutting height is strongly associated with plant production in the subsequent growth cycle (FAGUNDES et al., 1999). Therefore, optimal post-grazing residual height could make it easier to identify over-use in non-conventional crops. We hypothesized that increased seeding rate is associated with high plant stand and lower nutritive value. Additionally, lower cutting height decreases plant height and increases forage nutritional value at grazing time. So, this study aimed to evaluate seeding rate and cutting heights on production and composition of millet.

\section{Material and Methods}

Experiments were conducted in Agrarian Sciences Center of the Federal University of São Carlos in Araras, SP, Brazil. Two randomized block design experiments were performed. In the first trial, 32 parcels $(1.2 \times 1.2 \mathrm{~m})$ were used to evaluate the following seeding rates: 24,35 , 50 and $60 \mathrm{~kg}$ of seeds per hectare. Mechanical cuts were performed at 45, 70 and 105 days after seeding. Plant height was measured using three points per $\mathrm{m}^{2}$. Whole parcels were cut at $30 \mathrm{~cm}$ of height and samples were collected for bromatological analysis.

In the second trial, 20 parcels $(1.2 \times 3 \mathrm{~m})$ were used to evaluate the following cutting height: $20,30,40$ and 50 $\mathrm{cm}$. The residual heights were determined according to the methodology described by Jornada et al. (2008). Forty-five days after seeding, a leveling cut was performed to provide treatment application. Samples were performed at 30 and 60 days after the first treatment application. Plant height was measured using three points per $\mathrm{m}^{2}$. Two random samples of $1 \times 1 \mathrm{~m}\left(1 \mathrm{~m}^{2}\right)$ each were performed per parcel (PENATI et al., 2005). Sampling was performed using a quadrant of metal and at least $10 \mathrm{~cm}$ of border.

Chemical composition of soil and climatic condition are shown in Table 1 and Figure 1, respectively. Millet seed of BRS-1501 cultivar (Piraí Sementes, Piracicaba, Brazil), 
with $95 \%$ of purity and $75 \%$ of germination rate were used. Seeding was performed on the 15th of November 2014. After cuts, each parcel was individually fertilized with $50 \mathrm{~kg} \mathrm{~N} / \mathrm{ha}$ of urea and irrigated daily during the trials. Disposable fresh mass production was evaluated using a scale (BL3200H, Shimadzu', São Paulo, Brazil). Two samples per parcel, of approximately $300 \mathrm{~g}$, were collected and pre-dried at $60{ }^{\circ} \mathrm{C}$ in a forced air oven for 72 hours and subsequently processed in a knives Willey mill with 1 (Method 950.02) (WORWITZ, 2000) and $2 \mathrm{~mm}$ pore screen, which were used for chemical analysis and ruminal incubation, respectively.

Table 1 - Soil chemical composition before millet seeding Araras, Brazil, 2016

\begin{tabular}{lcc}
\hline \multirow{2}{*}{ Item } & \multicolumn{2}{c}{ Sampling depth $\mathbf{( c m})$} \\
\cline { 2 - 3 } & $\mathbf{0 - 2 0}$ & $\mathbf{2 0 - 4 0}$ \\
\hline Organic Matter, g/L & 62 & 41 \\
$\mathrm{pH}$ & 5.9 & 6.2 \\
Phosphorus, mg/L & 660 & 510 \\
Potassium, mmol/L & 15 & 15 \\
Calcium, mmol/L & 95 & 73 \\
Magnesium, mmol/L & 25 & 22 \\
Aluminium, mmol/L & 0.5 & 0.4 \\
CEC ${ }^{1}, \mathrm{mmol} / \mathrm{L}$ & 160 & 129 \\
Sulfur, mg/L & 109 & 60 \\
Boron, mg/L & 0.53 & 0.4 \\
Cupper, mg/L & 4.8 & 2.7 \\
Iron, mg/L & 61 & 45 \\
Magnesium, mg/L & 27.6 & 21.7 \\
Zinc, mg/L & 12.0 & 9.4 \\
\hline
\end{tabular}

${ }^{1}$ CEC: cation-exchange capacity
Samples were analyzed for dry matter (method 930.15) (WORWITZ, 2000), crude protein $(\mathrm{N} \times 6.25$; method 984.13) (WORWITZ, 2000) and neutral detergent fiber (NDF), using Van Soest et al. (1991) detergents and digestion for one hour at $90{ }^{\circ} \mathrm{C}$. Acid detergent lignin (ADL) was analyzed using 72 percent sulfuric acid (VAN SOEST et al., 1991). For in situ digestibility evaluation, approximately $500 \mathrm{mg}$ were weighed, placed in $5 \times 5$ $\mathrm{cm}$ bags and ruminal incubated for 96 hours, in two ruminal cannulated dairy cows, fed with $700 \mathrm{~g} / \mathrm{kg}$ of corn silage. After ruminal removal, bags were water washed, pre-dried at $60^{\circ} \mathrm{C}$ for 24 hours and dried for one hour at $105^{\circ} \mathrm{C}$. Then, bags were washed in NDF solution (VAN SOEST et al., 1991), for one hour at $90^{\circ} \mathrm{C}$. Digestibility of NDF (NDFd) was estimated according to the following equation:

$$
\operatorname{NDFd}\left(\frac{\mathrm{g}}{\mathrm{kg}}\right)=\operatorname{NDF}\left(\frac{\mathrm{g}}{\mathrm{kg}}\right)-\mathrm{iNDF}\left(\frac{\mathrm{g}}{\mathrm{kg}}\right)
$$

Where, NDF was the forage NDF concentration and iNDF was the indigestible NDF concentration. Data were analyzed as repeated measures, using the MIXED procedure of SAS 9.3 (SAS INSTITUTE, 2011), according to the following model:

$$
Y_{i j k}=\mu+T_{i}+b_{j}+\omega_{i j}+C_{k}+T_{i} \times \mathrm{C}_{k}+e_{i j k}
$$

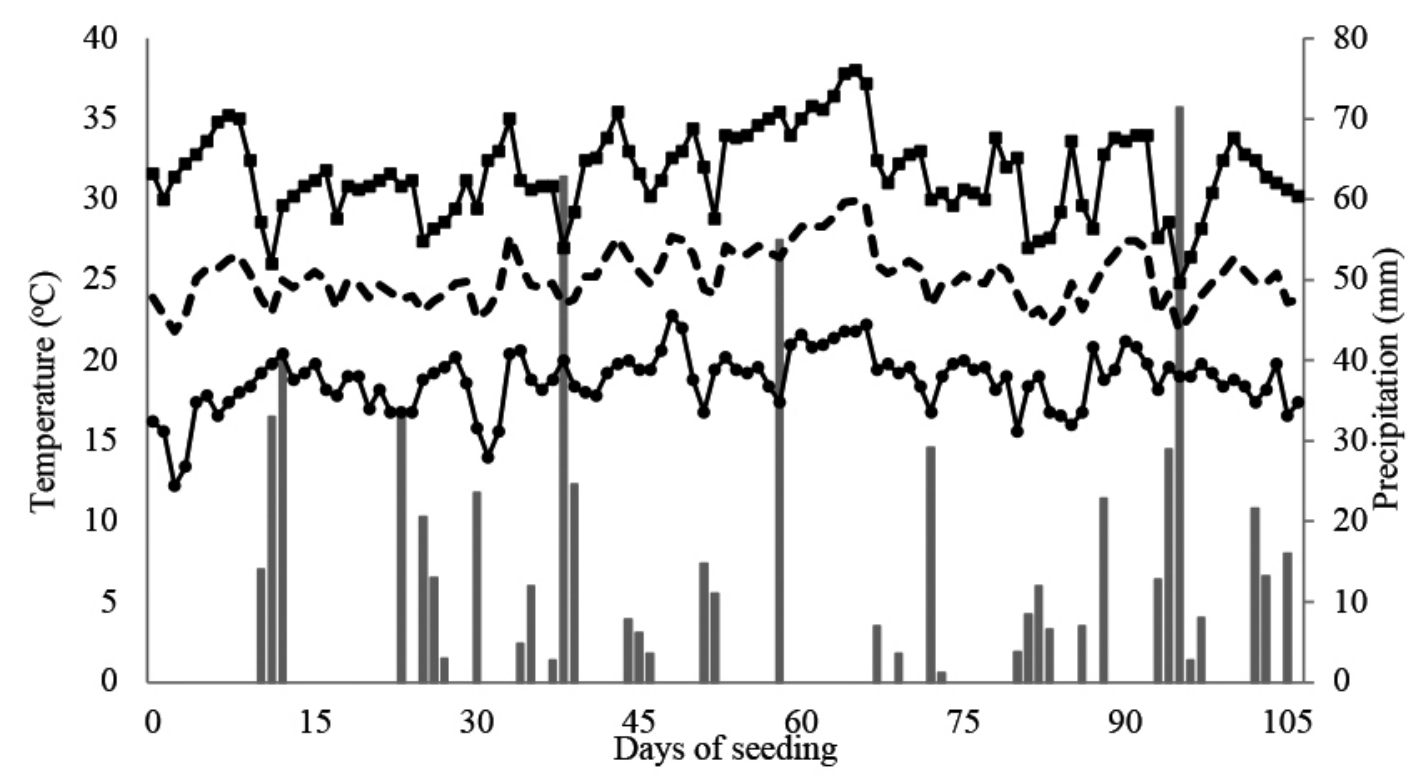

Figure 1 - Temperature and precipitation 
Where $Y_{i j k}$ is the value observed in the $\mathrm{k}$ growth cycle, for parcel percentage to the $\mathrm{j}$ block, which received treatment $i$; $\mu$ was the overall mean; $T_{i}$ was the fixed effect of treatment i ( $\mathrm{i}=1$ to 4 in both experiments); $b_{j}$ was the random effect of block $j(j=1$ to 5 at residual height experiment and $j=1$ to 8 at seeding rates trial); $\omega_{i j}$ was the random error associated with parcels; $C_{k}$ was the cycle fixed effect ( $k=1$ to 2 at residual height trial and $j=1$ to 3 the seeding rate experiment); $T_{i} \times \mathrm{C}_{k}$ was the fixed effect of the treatment and cycle interaction and $\mathrm{e}_{i j k}$ was the subplot random error. Kenward and Rogers (1997) method was used for degrees of freedom correction and covariance structure chosen were performed according to the Akaike method. Treatment effects were studied by orthogonal contrasts (linear and quadratic). Significance was declared at $\mathrm{P} \leq 0.05$, except in specific situations where the exact probability value was presented. Data from two experiments were subjected to correlation analysis using PROC CORR (SAS 9.3).

\section{Results and Discussion}

There was significant growth cycle and seeding rate interaction effects on fresh mass production $(\mathrm{P} \leq 0.05$; Table 2). Seeding rate linearly increased fresh mass production during the two first cycles $(\mathrm{P}=0.011$; Figure 2) and had no effect on the third cycle in fresh mass production $(\mathrm{P}=0.101)$. Regardless of the evaluated growth cycle, seeding rate linearly increased plant height and dry mass production $(\mathrm{P}=0.029)$. These results could be associated with increased plant density, which was more evident in the two first cycles. Plant competition for light stimulates apical dominance and consequently increases plant height (YAN et al., 2012). Moreover, in the initial growth cycles, the tillers density has a strong correlation with forage mass production (CUNHA et al., 2011).

Pereira Filho et al. (2003) observed that 15 to $20 \mathrm{~kg} / \mathrm{ha}$ of seeds are recommended for millet pasture establishment. However, greater tillering power of the plants can compensate for lower seeding rates. Carberry et al. (1985) studied plant population from 50,000 to 400,000 plants per hectare and found $77 \%$ decrease in total weight per plant and 66\% reduction in leaf area per plant with higher density and recommended 150,000 plants per hectare. However, despite great millet tillering capacity, in this study, the higher seeding rate $(60 \mathrm{~kg} / \mathrm{ha})$ showed higher production on the first two growth cycles. In a practical situation, higher seeding rate could reduce plant age at first grazing, without altering forage composition and probably without major effects on digestibility.

There was no effect of seeding rate on DM and NDF concentration ( $\mathrm{P}>0.10$; Table 2). Anjum and Cheema (2016) found 698, 718 and $671 \mathrm{~g} / \mathrm{kg}$ of NDF concentration for fresh millet, silage and hay, respectively, slightly lower than $740 \mathrm{~g} / \mathrm{kg}$ of NDF found in this study. However, the former study used millet with $310 \mathrm{~g} / \mathrm{kg}$ of dry matter, at silage cut point, higher than $114 \mathrm{~g} / \mathrm{kg}$ in our analysis. On the other hand, Rosser et al. (2013) observed $520 \mathrm{~g} / \mathrm{kg}$ of $\mathrm{NDF}$ and $140 \mathrm{~g} / \mathrm{kg}$ of dry matter in the head elongation phase. Pariz et al. (2011) found 742 and $642 \mathrm{~g} / \mathrm{kg}$ of NDF in dry and rainy season, respectively. There was no effect of seeding rate on NDF and CP concentration. Additionally, we found higher NDF content than Rosser et al. (2013), even using plants before head elongation phase. Crude protein concentration averaged $152 \mathrm{~g} / \mathrm{kg}$, similarly to Rosser et al. (2013) (186 g/kg at head elongation phase) and Tiritan et al., (2013) (146 g/kg; 30 days after sowing).

Concentration of ADL averaged 48.3 and $65.5 \mathrm{~g} / \mathrm{kg}$ of DM and NDF, respectively, but was not affected by seeding rate. Increased seeding rate had no effect on NDFd but tended to decrease DM digestibility $(\mathrm{P}=0.089)$, which resulted in no effect on digestible DM production $(P=0.153)$. However, Rosser et al. (2013) found a quadratic increase of digestible mass production according to millet growth. According to these authors, the lack of decline in DM and OM digestibility as plants matured could be explained by non-fiber carbohydrate increase and NDF and $\mathrm{CP}$ concentration decrease. In this study, there was no effect of seeding rate on $\mathrm{ADL}, \mathrm{NDF}$ and $\mathrm{CP}$ concentrations and DM digestibility decrease seems to be associated with morphology modification. When data of both two experiments were analyzed, the main factor associated with $\mathrm{DM}$ digestibility was plant height $(\mathrm{P}=0.032$; $\mathrm{R}=-0.185)$ and ADL could not be associated $(\mathrm{P}=0.489)$, although Tylutki et al. (2008) used lignin for carbohydrate indigestible fraction estimation.

Plant height, DM concentration and DM production linearly increased with increased cutting height $(\mathrm{P}=0.008$; Table 3). Increased DM content could be associated with plant growth stage modification (CARBERRY et al., 1985; MÜLLER et al., 2006). Yet, Pariz et al. (2011) observed no effect of seeding time on total digestible nutrients throughout the seasons, as higher post-grazing increases remaining leaves, which are older at the end of the next 
growth cycle. Increased dried leaves associated with higher post-grazing residual height had higher effects on chemical composition and in situ digestibility of millet than increased plant density or seeding rate. The average $\mathrm{DM}$ production using $30 \mathrm{~cm}$ of cutting height in our trial (2.24 ton/ha) was like Schwartz et al. (2003) and higher than reported for Brum et al. (2008), Camargo et al. (2009), and Da Silva et al. (2014). There were no effects of cutting heights on forage NDF and CP content and DM digestibility. However, NDFd tended to decrease when post-grazing residual height increased $(\mathrm{P}=0.052)$. Decreased NDFd could be associated with increased ADL concentration (TYLUTKI et al., 2008). Meanwhile, post-grazing residual height had no effect on $\mathrm{DM}$ digestibility ( $\mathrm{P}=0.205)$. Leão et al. (2012), studied millet genotypes managed at different heights and found lower lignin contents and higher nutritional value and digestibility in lower heights. Detmann et al. (2014) highlighted that the NDF digestibility is one of the most important feed intake determinants and may directly affect animal performance.

Table 2 - Millet production and chemical composition according to different seeding rates for three growth cycles - Araras, Brazil, 2016

\begin{tabular}{|c|c|c|c|c|c|c|c|c|c|}
\hline \multirow{2}{*}{ Item } & \multicolumn{4}{|c|}{ Seeding rates ${ }^{1}$} & \multirow{2}{*}{ SEM $^{2}$} & \multicolumn{4}{|c|}{ Probabilities } \\
\hline & 24 & 35 & 50 & 60 & & Cycle & Int. $^{3}$ & Linear $^{4}$ & Quad. $^{5}$ \\
\hline Height, $\mathrm{cm}$ & 146 & 149 & 151 & 152 & 1.31 & 0.245 & 0.765 & 0.029 & 0.622 \\
\hline Fresh mass, ton/ha & 30.2 & 38.2 & 41.6 & 45.2 & 1.39 & 0.011 & 0.043 & 0.001 & 0.472 \\
\hline Dry mass, ton/ha & 3.73 & 4.27 & 4.71 & 4.81 & 0.19 & $<0.001$ & 0.696 & 0.027 & 0.565 \\
\hline Digestible mass, ton/ha & 2.48 & 2.75 & 3.00 & 2.96 & 1.19 & $<0.001$ & 0.701 & 0.153 & 0.577 \\
\hline \multicolumn{10}{|l|}{ Forage composition, $\mathrm{g} / \mathrm{kg}$} \\
\hline Dry Matter & 120 & 112 & 116 & 108 & 3.0 & $<0.001$ & 0.726 & 0.158 & 0.950 \\
\hline NDF$^{6}$ & 730 & 751 & 733 & 736 & 4.3 & $<0.001$ & 0.419 & 0.908 & 0.158 \\
\hline Crude protein & 156 & 155 & 146 & 150 & 2.6 & 0.401 & 0.762 & 0.227 & 0.736 \\
\hline $\mathrm{ADL}^{7}$ & 49.5 & 46.0 & 50.5 & 47.2 & 0.7 & 0.039 & 0.268 & 0.844 & 0.853 \\
\hline$A D L^{7}, \mathrm{~g} / \mathrm{kg}$ of $\mathrm{NDF}^{6}$ & 68.0 & 61.2 & 68.7 & 64.2 & 0.1 & $<0.001$ & 0.110 & 0.872 & 0.613 \\
\hline \multicolumn{10}{|l|}{ In situ digestibility, g/kg } \\
\hline Dry matter & 667 & 644 & 642 & 623 & 8.0 & 0.061 & 0.893 & 0.089 & 0.898 \\
\hline $\mathrm{NDF}^{6}$ & 559 & 508 & 550 & 522 & 12.3 & 0.045 & 0.149 & 0.625 & 0.636 \\
\hline
\end{tabular}

${ }^{1} 24,35,50$ and $60 \mathrm{~kg}$ of seeds per hectare. ${ }^{2}$ SEM: standard error of means; ${ }^{3}$ Int: treatments and cycle interaction effect; ${ }^{4}$ Linear: linear effect of seeding rates; ${ }^{5} \mathrm{Quad} .:$ quadratic effect of seeding rates; ${ }^{6} \mathrm{NDF}$ : neutral detergent fiber; ${ }^{7} \mathrm{ADL}$ : acid detergent lignin

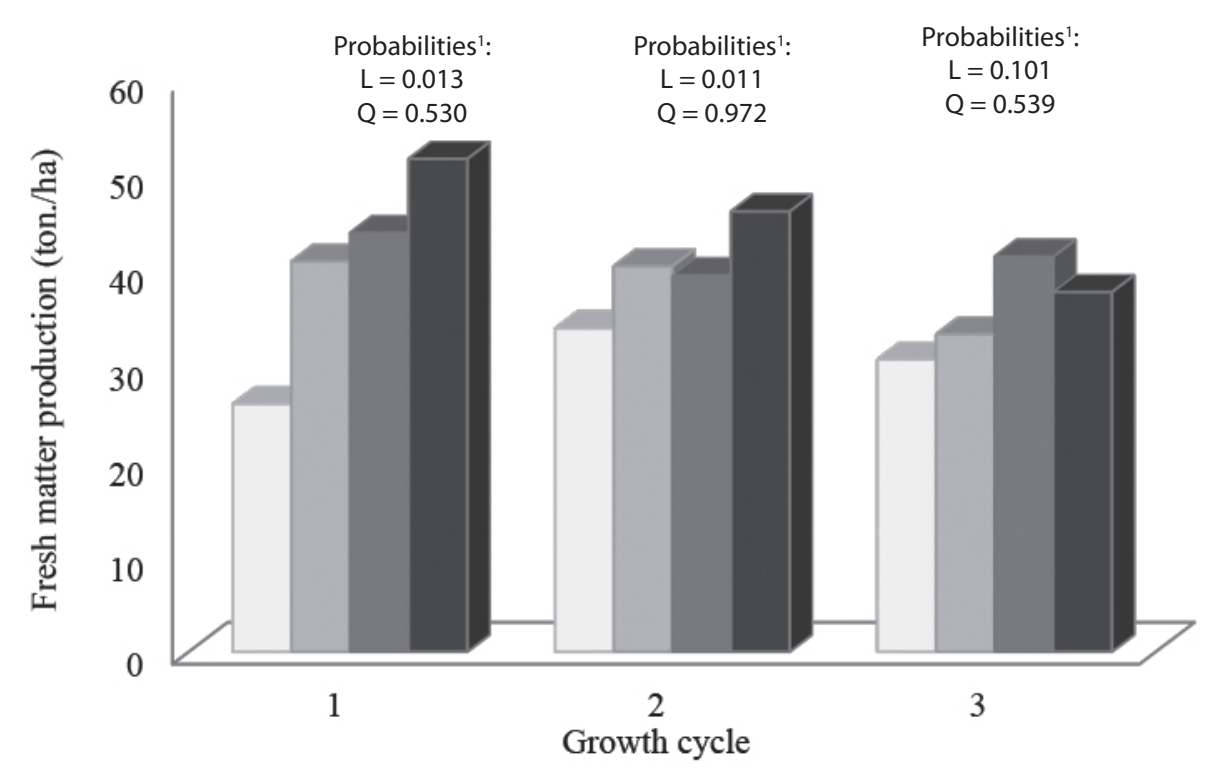

Figure 2 - Millet fresh matter production with $24(\square), 35(\square), 50(\square)$ and $60(\square) \mathrm{kg} / \mathrm{ha}$ of seeding rates for three growth cycles. ${ }^{1}$ Probabilities: linear and quadratic effect of seeding rate in each growth cycle 
Table 3 - Millet production with different cutting heights for two growth cycles - Araras, Brazil, 2016

\begin{tabular}{|c|c|c|c|c|c|c|c|c|c|}
\hline \multirow{2}{*}{ Item } & \multicolumn{4}{|c|}{ Cutting heights ${ }^{1}$} & \multirow{2}{*}{ SEM $^{2}$} & \multicolumn{4}{|c|}{ Probabilities } \\
\hline & 20 & 30 & 40 & 50 & & Cycle & Int. $^{3}$ & Linear $^{4}$ & Quad. ${ }^{5}$ \\
\hline Height, cm & 145 & 153 & 155 & 160 & 1.81 & 0.647 & 0.885 & 0.002 & 0.523 \\
\hline Fresh mass, ton/ha & 33.1 & 39.5 & 41.7 & 43.5 & 1.57 & 0.293 & 0.156 & 0.270 & 0.620 \\
\hline Dry mass, ton/ha & 3.50 & 4.52 & 4.93 & 5.52 & 0.247 & 0.001 & 0.642 & 0.008 & 0.675 \\
\hline Digestible mass, ton/ha & 2.09 & 2.61 & 2.90 & 3.16 & 0.153 & $<0.001$ & 0.378 & 0.008 & 0.620 \\
\hline \multicolumn{10}{|l|}{ Forage composition, $\mathrm{g} / \mathrm{kg}$} \\
\hline Dry matter & 103 & 114 & 115 & 126 & 2.5 & 0.046 & 0.210 & $<0.001$ & 0.955 \\
\hline $\mathrm{NDF}^{7}$ & 720 & 707 & 707 & 717 & 6.6 & $<0.001$ & 0.494 & 0.843 & 0.214 \\
\hline Crude protein & 173 & 171 & 166 & 171 & 2.8 & 0.026 & 0.288 & 0.730 & 0.534 \\
\hline$A D L$ & 147 & 162 & 155 & 172 & 3.9 & 0.094 & 0.334 & 0.085 & 0.933 \\
\hline $\mathrm{ADL}^{8}, \mathrm{~g} / \mathrm{kg} \mathrm{NDF}$ & 204 & 230 & 220 & 239 & 5.4 & 0.800 & 0.216 & 0.096 & 0.785 \\
\hline \multicolumn{10}{|l|}{ In situ digestibility, g/kg } \\
\hline Dry matter & 592 & 577 & 589 & 566 & 8.3 & 0.001 & 0.324 & 0.205 & 0.733 \\
\hline $\mathrm{NDF}^{7}$ & 478 & 460 & 486 & 423 & 12.0 & 0.041 & 0.339 & 0.052 & 0.147 \\
\hline
\end{tabular}

${ }^{1} 20,30,40$ and $50 \mathrm{~cm}$ of cutting heights. ${ }^{2}$ SEM: standard error of means; ${ }^{3}$ Int: treatments and cycle interaction effect; ${ }^{4}$ Linear: linear effect of seeding rates; ${ }^{5} \mathrm{Quad} .:$ quadratic effect of cutting height; ${ }^{6}$ Cubic: Cubic effect of cutting height; ${ }^{7} \mathrm{NDF}$ : neutral detergent fiber; ${ }^{8} \mathrm{ADL}$ : acid detergent lignin

\section{Conclusion}

Higher seeding rate $(60 \mathrm{~kg} / \mathrm{ha})$ increased plant height and dry mass production, and tended to decrease DM in situ digestibility, without any effect on chemical composition and digestible DM production. Higher cutting height $(50 \mathrm{~cm})$ provided higher residual plant height, fresh and dry mass production, digestible DM production, tended to increase ADL concentration and decreased NDF in situ digestibility.

\section{References}

ALENCAR, W. M.; RESTLE, J.; MISSIO, R. L.; NEIVA, J. N. M.; MIOTTO, F. R. C.; FREITAS, I. B. Feeding behavior and productive performance of steers fed pearl millet grainbased diets containing proportions of babassu mesocarp bran. Revista Brasileira de Zootecnia, v. 44, n. 12, p. 425433, 2015. doi: 10.1590/S1806-92902015001200003.

ANJUM, M. I.; CHEEMA, A. U. Feeding value of millet harvested as silage or hay fed to buffalo calves supplemented with concentrate on growth performance and nutrient digestibility. Pakistan Journal of Zoology, v. 48, n. 1, p. 101-105, 2016.

BRUM, M. S.; QUADROS, F. L. F.; MARTINS, J. D.; ROSSI, G. E.; DANIEL, E.; MAIXNER, A. R.; BANDINELLI, D. G. Feeding systems for sheep rearing on pasture: evaluation of animal performance and forage characteristics. Ciência Rural, v. 38, n. 1, p. 191-198, 2008. doi: 10.1590/S010384782008000100031.

CAMARGO, D. G.; ROCHA, M. G.; KOZLOSKI, G. V.; ELEJALDE, D. G.; BREMM, C.; PÖTTER, L.; ROSA,
A. T. N.; OLIVEIRA NETO, R. A. Forage intake by supplemented lambs on pearl millet pasture. Ciência Rural, v. 39, n. 2, p. 509-514, 2009. doi: 10.1590/S010384782008005000083.

CARBERRY, P. S.; CAMPBELL, L. C.; BIDINGER, F. R. The growth and development of pearl millet as affected by plant population. Field Crops Research, v. 11, n. 2-3, p. 193-205, 1985. doi: 10.1016/0378-4290(85)90102-9.

CASTRO, C. R. C. Relações planta-animal em pastagem de milheto. (Pennisetum americano (L.) Leeke) manejada em diferentes alturas com ovinos. 2002. 200 f. Dissertação (Mestrado em Zootecnia) - Faculdade de Agronomia, Universidade Federal do Rio Grande do Sul, Porto Alegre, 2002.

CUNHA, M. V.; LIRA, M. A.; SANTOS, M. V. F.; FREITAS, E. V.; DUBEUX JÚNIOR, J. C. B.; MELLO, A. C. L.; MARTINS, K. G. R. Association between the morphological and productive characteristics in the selection of elephant grass clones. Revista Brasileira de 
Zootecnia, v. 40, n. 3, p. 482-488, 2011. doi: 10.1590/S151635982011000300004 .

DA SILVA, A. G.; FRANÇA, A. F. D. S.; MIYAGI, E. S.; DAMBROS, C. E.; LOPES, F. B. Efficiency of nitrogen and phosphate fertilization on pearl millet cultivars. Ciência Animal Brasileira, v. 15, n. 2, p. 119-127, 2014. doi: 10.1590/1809-6891v15i29010.

DETMANN, E.; VALENTE, E. E. L.; BATISTA, E. D.; HUHTANEN, P. An evaluation of the performance and efficiency of nitrogen utilization in cattle fed tropical grass pastures with supplementation. Livestock Science, v. 162, p. 141-153, 2014. doi: 10.1016/j.livsci.2014.01.029.

FAGUNDES, J. L.; SILVA, S. C.; PEDREIRA, C. G. S.; CARnevalli, R. A.; CARVAlHO, C. A. B.; SBRISSIA, A. F.; PINTO, L. F. M. Grazing intensities and the morphological composition of Cyonodon spp. pastures. Scientia Agricola, v. 56, n. 4, p. 897-908, 1999. doi: 10.1590/S0103-90161999000400017.

GERBER, P. J.; MOTTET, A.; OPIO, C. I.; FALCUCCI, A.; TEILLARD, F. Environmental impacts of beef production: review of challenges and perspectives for durability. Meat Science, v. 109, n. 109, p. 2-12, Nov. 2015. doi: 10.1016/j.meatsci.2015.05.013.

HERINGER, I.; MOOJEN, E. L. Productive potential, structure changes and quality of pearl millet under different nitrogen levels. Revista Brasileira de Zootecnia, v. 31, n. 2, p. 875-882, 2002. doi: 10.1590/S151635982002000400010 .

HIRATA, A. C. S.; HIRATA, E. K.; BARRIONUEVO, R. M.; MONQUERO, P. A. Pearl millet crop management for no-tillage crisphead lettuce in the summer with or without beds. Horticultura Brasileira, v. 33, n. 3, p. 398-403, 2015. doi: 10.1590/S0102-053620150000300021.

JORNADA, J. B. J.; MEDEIROS, R. B.; PEDROSO, C. E. S.; SAIBRO, J. C.; SILVA, M. A. Efeito da irrigação, épocas de corte da forragem e doses de nitrogênio sobre a qualidade de sementes de milheto (Pennisetum americanum (L.) Leeke). Revista Brasileira de Sementes, v. 30, n. 3, p. 10-15, 2008. doi: 10.1590/S010131222008000300002 .
KENWARD, M. G.; ROGER, J. H. Small sample inference for fixed effects from restricted maximum likelihood. Biometrics, v. 53, n. 3, p. 983-997, 1997. doi: 10.2307/2533558.

LEÃO, H. F.; COSTA, K. A. P.; DIAS, F. J. S.; SEVERIANO, E. C.; COLLAO-SAENZ, E. A.; SIMON, G. A. Production and bromatological composition of pearl millet genotypes for pasture manned in different cutting heights. Bioscience Journal, v. 28, n. 6, p. 903-912. 2012.

MONTAGNER, D. B.; ROCHA, M. G.; SANTOS, D. T.; GENRO, T. C. M.; QUADROS, F. L. F.; ROMAN, J.; PÖTTER, L.; BREMM, L. Pearl Millet pasture management for rearing of beef heifers. Ciência Rural, v. 38, n. 8, p. 2293-2299, 2008. doi: 10.1590/S0103-84782008000800031.

MÜllER, L.; SANTOS, O. S.; MANFROM, P. A.; MEDEIROS, S. L. P.; HAUT, V.; DOURADO NETO, D.; MENEZES, N. L.; GARCIA, D. C. Hydroponic millet forage: production and naurishing quality in different sowing densities and harvest ages. Ciência Rural, v. 36, n. 4, p. 1094-1099. 2006. doi: 10.1590/S010384782006000400008 .

NELSON, T. The grass leaf developmental gradient as a platform for a systems understanding of the anatomical specialization of $\mathrm{C} 4$ leaves. Journal of Experimental Botany, v. 62, n. 9, p. 3039-3048, 2011. doi: 10.1093/jxb/ err072.

PARIZ, C. M.; AZENHA, M. V.; ANDREOTTI, M.; ARAÚJO, F. C. M.; ULIAN, N. A.; BERGAMASCHINE, A. F. Yield and chemical composition of forage in croplivestock integration in different sowing time. Pesquisa Agropecuária Brasileira, v. 46, n. 10, p. 13921400, 2011. doi: 10.1590/S0100-204X2011001000037.

PEDROSO, C. E. S.; MONKS, P. L.; FERREIRA, O. G. L.; TAVARES, O. M.; LIMA, L. S. Structural characteristics of pearl millet under rotational grazing with different rest periods. Revista Brasileira de Zootecnia, v. 38, n. 5, p. 801-808. 2009. doi: 10.1590/S1516-35982009000500004

PENATI, M. A.; CORSI, M.; LIMA, C. G.; MARTHA JÚNIOR, G. B.; DIAS, C. T. S. Number of sampling and dimension:format ratio of the quadrat for herbage 
mass determination in tussock-forming grasses. Revista Brasileira de Zootecnia, v. 34, n. 1, p. 36-43. 2005. doi: 10.1590/S1516-35982005000100005

PEREIRA FILHO, I. A.; FERREIRA, A. S.; COELHO, A. M.; CASELA, C. R.; KARAM, D.; RODRIGUES, J. A. S.; CRUZ, J. C.; WAQUIL; J. M. Manejo da cultura do milheto. Sete Lagoas: Embrapa Milho e Sorgo, 2003. 17 p. (Embrapa Milho e Sorgo, Circular Técnica n. 29).

RIZO, L. M.; MOOJEN, E. L.; DE QUADROS, F. L. F.; CÔRREA, F. L.; JÚNIOR, J. A. F. Performance of native pasture and pasture sodseeded with winter species with or without glyphosate. Ciência Rural, v. 34, n. 6, p. 1921-1926, 2004. doi: 10.1590/S0103-84782004000600039.

ROSSER, C. L.; GÓRKA, P.; BEATTIE, A. D.; BLOCK, H. C.; MCKINNON, J. J.; LARDNER, H. A.; PENNER, G. B. Effect of maturity at harvest on yield, chemical composition, and in situ degradability for annual cereals used for swath grazing. Journal of Animal Science, v. 91, n. 8, p. 3815-3826, 2013. doi: 10.2527/ jas.2012-5677.

SAS INSTITUTE. SAS User's Guide: statistics, version 9.3. Cary: SAS, 2011. $2340 \mathrm{p}$.

SCARAVELLI, L. F. B.; PEREIRA, L. E. T.; OLIVO, C. J.; AGNOLIN, C. A. Production and quality of Coastcross-1 and pearl millet pastures utilized with dairy cows. Ciência Rural, v. 37, n. 3, p. 841-846, 2008. doi: 10.1590/S010384782007000300037.

SCHWARTZ, F.; ROCHA, M.; VERAS, M. G.; FARINATTI, L. H.; PIRES, C. C.; CELLA JUNIOR, A. A. Pearl millet (Pennisetum americanum leeke) management under sheep grazing. Revista Brasileira de Agrociência, v. 9, n. 2, p. 151-155, 2003.

SOUSA NETO, E. L.; ANDRIOLI, I.; BEUTLER, A. N.; CENTURION, J. F. Soil physical attributes and corn yield as a response to cover crops prior to corn. Pesquisa Agropecuária Brasileira, v. 43, n. 2, p. 255-260, 2008. doi: 10.1590/S0100-204X2008000200015.

TIRITAN, C. S.; SANTOS, D. H.; MINUTTI, C. R.; FOLONI, J. S. S.; CALONEGO, J. C. Bromatological composition of sorghum, millet plant and midgetguandu at different cut times in intercropping and monoculture. Acta Scientiarum. Agronomy, v. 35, n. 2, p. 183-190, 2013. doi: 10.4025/actasciagron.v35i2.15772.

TYLUTKI, T. P.; FOX, D. G.; DURBAL, V.M.; TEDESCHI,L. O.; RUSSELL, J. B.; VAN AMBURGH, M. E.; OVERTON, T. R.; CHASE, L. E.; PELL, A. N. Cornell Net Carbohydrate and Protein System: a model for precision feeding of dairy cattle. Animal Feed Science and Technology, v. 143, n. 1-4, p. 174-202, 2008. doi: 10.1016/j.anifeedsci.2007.05.010.

VAN SOEST, P. J.; ROBERTSON, J. B.; LEWIS, B. A. Methods for dietary fiber, neutral detergent fiber, and nonstarch polysaccharides in relation to animal nutrition. Journal of Dairy Science, v. 74, n. 10, p. 3583-97, 1991. doi: 10.3168/jds.S0022-0302(91)78551-2.

WORWITZ, W. (Ed.). Official methods of analysis of AOAC International. 17th. ed. Gaithersburg: AOAC International, 2000. $2200 \mathrm{p}$.

YAN, E.-R.; MILLA, R.; AARSSEN, L. W.; WANG, X.-H. Functional relationships of leafing intensity to plant height, growth form and leaf habit. Acta Oecologica, v. 41, p. 20-29, May 2012. doi: 10.1016/j.actao.2012.04.001. 